\title{
Virtual Reality for Pain Management to Tackle the Opioid Crisis
}

\author{
Sudarshan Ramanan ${ }^{1}$ and Ajay S. Yekkirala ${ }^{2}$ \\ ${ }^{1}$ Boston University Academy, Boston, MA, USA \\ ${ }^{2}$ Blue Therapeutics, Waltham, MA, USA
}

\section{ABSTRACT}

The opioid crisis is a serious public health issue of epidemic proportions, building over the past decades. Prescription opioid abuse is one of the key sources of this issue. While pain is usually managed using pharmacological approaches, such as opioids, they produce several unwanted side effects - including respiratory depression and addiction - nonpharmacological approaches can be significant with minimal or no side effects. Recent developments in technology, such as Virtual Reality (VR), show considerable promise for main-stream adoption as one of the non-pharmacological interventions. Preventing a patient's transition from acute to chronic pain is one instance where VR can presumably be effective. However, challenges remain due to the inherent subjectivity and lack of clear baselines in clinical intervention studies. Here, we review recent studies on the application of VR as a treatment for acute and chronic pain management to primarily understand key technical challenges faced by VR. The secondary goal of this work is to identify possible options to tackle some of the key challenges. Design considerations emerge as one critical component in improving patient engagement.

\section{Introduction}

Opioids are potent analgesics that are still the standard of care to manage pain in clinical settings (HHS, 2019). However, controlling their use for managing pain and minimizing the morbidity and mortality associated with its misuse and abuse, is the biggest challenge faced in the healthcare system. Indeed, the ongoing opioid crisis lies at the intersection of two substantial public health challenges - reducing the burden of suffering from pain and containing the rising toll of the harms that can result from the use of opioid medications, according to HHS. Between 1999 and 2017, more than 700,000 people have died from drug overdose. Roughly $21-29 \%$ of patients who were prescribed opioids for chronic pain misuse them (Centers for Disease Control and Prevention, 2020).

According to the American Psychiatric Association, the criteria for Opioid Use Disorder (OUD) includes a) consumption of opioids in larger amounts or longer than intended and b) persistent desire or unsuccessful efforts to control or cut down opioid use (Schuckit, 2016). While the use of a pharmacological approach (drug use) starts with the objective to manage pain, the very use of drugs makes patients vulnerable to slip into opioid addiction, which is a form of substance use disorder (SUD). Thus, this becomes a vicious cycle resulting in serious economic repercussions for the healthcare system and compromises the quality of life for the patient (White House Report, 2017). Based on its duration, pain is classified into two main types- acute and chronic. The lack of adequate attention and care can 
transition a person from acute to chronic state and hence increase incidence of opioid use and potentially its misuse (Glare et al., 2019). In the fight against opioid misuse, it is important that the gateways or pathways that cause this slippery slope are understood and addressed.

Based on type and severity of pain, it is commonly treated via drugs (pharmacological), non-medications (non-pharmacological), or a combination of these two methods (HHS, 2019). For most clinical indications, pharmacological approaches have been the mainstay. However, the risks associated with imprecise titration, narrow therapeutic window, adverse side effects, the potential for drug misuse, and cost have driven patients and doctors to explore alternative non-pharmacological interventions. For any intervention to be effective and achieve mainstream adoption, the degree of treatment success on recovery (efficacy) and quality of life post-treatment are critical (Makin, 2019). Of the many non-pharmacological treatment types, Virtual Reality (VR) has shown considerable promise, especially due to recent advancements in gaming technologies and lower hardware costs (Delshad et al., 2018). Since 2018, there has been a strong surge in the number of studies that focus on VR as used in pain management. Despite such extensive research work, significant challenges still remain for mainstream adoption of this technology (Ventola, 2019).

The goals of this work are to understand the current state of VR application for pain management, identify key challenges, and offer perspectives on improvement. This paper provides a brief background on pain management and its common treatment types, before attempting to evaluate recent studies on VR-based interventions to treat pain. It systematically reviews the latest progress on this topic following a meta-analysis style of review. It focuses on the efficacy, key challenges, and opportunities for improvement in VR, which are critical for its mainstream adoption in pain management to mitigate the opioid crisis.

\section{The Challenge of Dealing with Pain}

The International Association for the Study of Pain (IASP) defines pain as an unpleasant sensory and emotional experience associated with actual or potential tissue damage. However, there are no objective measures for accurately gleaning how much pain a person perceives (Johnson, 2019). This further poses a major challenge in diagnosis. To help patients report the intensity of pain they experience, various quantitative and qualitative mechanisms, such as numerical rating scales (NRS) and visual analog scales (VAS), are being used (Jacques, 2020). Broadly, based on the intensity and nature of the pain, it can be classified into two main types - acute and chronic. Acute pain commonly results from disease, inflammation, or injury to tissues, such as broken bone, burn, fall, and dental work, and may usually last up to 3 months. This type of pain can be easily diagnosed and treated. On the other hand, chronic pain is believed to be a result of a chronic disease condition similar to diabetes or asthma and it lasts for more than 6 months. It is important that the pain is managed and conditions are treated. For example, constant exposure to intense pain and stress during medical and nursing procedures, can pose the risk of extended hospitalization. This can also transition a patient from an acute to chronic pain state. The exact mechanisms underlying the acute to chronic pain transitions are still unclear and is an ongoing topic of research (Glare et al., 2019). For example, chronic, postsurgical pain, occurring in approximately $10 \%$ of patients who have surgery, typically begins as acute postoperative pain that is difficult to control, but it soon transitions into a persistent pain condition. However, current studies have led to a stronger understanding of opioid-induced hyperalgesia and the use of more effective and safer opioid-sparing analgesic regimens. Indeed, it is now imperative that pain is managed by a non-pharmacological method as part of opioid-sparing repertoire (Schuckit, 2016). This is one of the primary drivers for this work. 


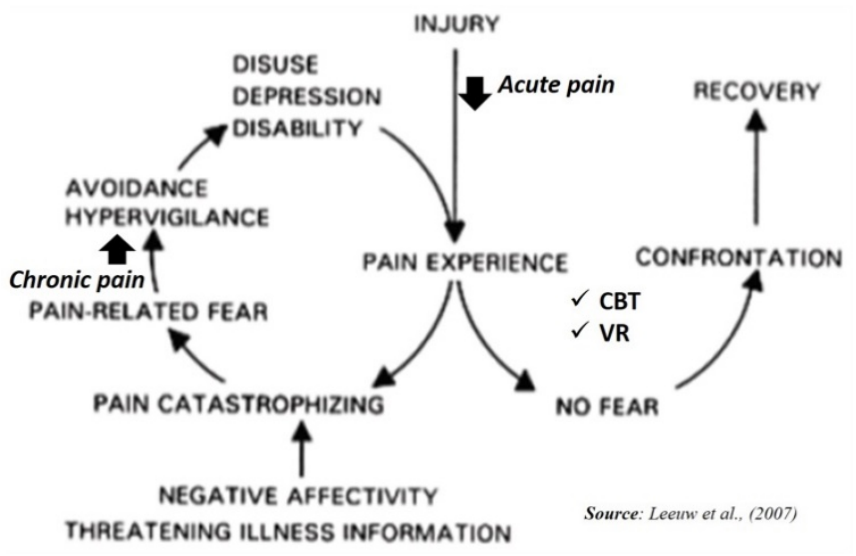

Figure 1. Fear Avoidance Model (adapted from Leeuw et al., 2007)

Fear also plays an important role in developing pain. The fear-avoidance model (Figure 1) for example describes how individuals develop chronic, musculoskeletal pain as a result of avoidant behavior based on fear (Leeuw et al., 2007). Many non-drug-based pain treatment approaches, such as cognitive behavioral therapy (CBT), distraction, and virtual environment-based therapies, have been found effective in treating fear avoidance and helping prevent chronic conditions.

\section{Pain Treatments}

Pain treatments can be categorized into one of the two following types based on what is involved in the treatment process.

a) Pharmacological: These are predominantly medication or drug-based treatments. Different types of medications are available for managing acute or chronic pain, which range from over-the-counter products to prescription medications. They mostly fall into one of the following categories: Narcotic (Opioids) Analgesics, Muscle Relaxants, Non-steroidal Anti-inflammatory Drugs (NSAIDs), Selective Norepinephrine Reuptake Inhibitors (SNRIs), Tricyclic Antidepressants, and Anticonvulsants (Pain Management Centers of New England, 2020). Of these, the opioid medications are the most effective due to their analgesic effects predominantly by binding to mu-opioid receptors. Mu-opioid receptors are densely concentrated in brain regions that regulate pain perception including pain-induced emotional responses (amygdala), and in brain reward regions that underlie the perception of pleasure and well-being. However, the same medications contribute to opioid addiction (Yekkirala et al., 2017). The rewarding effects of opioids play a major role in the risks of opioid diversion, overdose, and addiction.

b) Non-Pharmacological: These are non-medication-based therapies and include physical modalities, behavioral approaches, interventional approaches, and patient education. Examples include cognitive-behavior therapy (CBT), acceptance and commitment therapy (AACT), relaxation therapy, mindfulness-based stress reduction and hypnosis, Virtual Reality, and music therapy (HHS, 2019).

In practice, however, effective treatments often involve a combination of these two types of treatments, which are often called multi-modal treatments (Cuomo et al., 2019). 


\section{The Promise of Virtual Reality}

Virtual Reality (VR) refers to the interactions between an individual and a computer-generated environment, stimulating multiple sensory modalities, including visual, auditory, or haptic experiences. (Cornick, 2014). When a VR environment is immersive, it consumes cognitive and attentional resources through sensory input, which limits painprocessing capabilities. A proposed mechanistic theory of VR suggests that by stimulating the visual cortex while engaging other senses, VR acts as a distraction to limit the user's processing of nociceptive stimuli (Li et al., 2011). Distraction is a process in which attention is directed away from the nociceptive stimuli and changes the quality and quantity of pain, as perceived by the patient. The user's perception of immersive reality which leads to the feeling of "presence" (one's sense of being in the virtual world), is facilitated by the use of head-mounted displays (HMDs, in goggles or headsets), wall projectors, and/or gloves fitted with sensors or touch-sensitive motors along with additional user interaction mechanisms such as joysticks. Combination of the advancements in the field of digital therapeutics, the decline in gaming gadget prices, and the increased pressure to identify ways to minimize opioid use have contributed to a growing interest within the scientific community. In fact, within the past 10 years, there has been a steady increase in the number of studies on Virtual Reality as a treatment for clinical conditions, including acute and chronic pain management. Figure 2 shows the number of articles which have been published on topics of "virtual reality" and "pain" since 2010. Particularly, the surge in the number of publications within the past 3 years, clearly demonstrates the scientific community's interest and the dire need for better clinical solutions. Among these, many works also focused on meta-analysis and systematic reviews on previous studies to overcome difficulties in performing largescale randomized controlled trials (Ahn, 2018). These meta-analysis and systematic reviews (represented in solid black in Figure 2) followed recommended guidelines to help minimize study biases and improve their quality. These studies provide valuable insight into the state of VR on pain management.

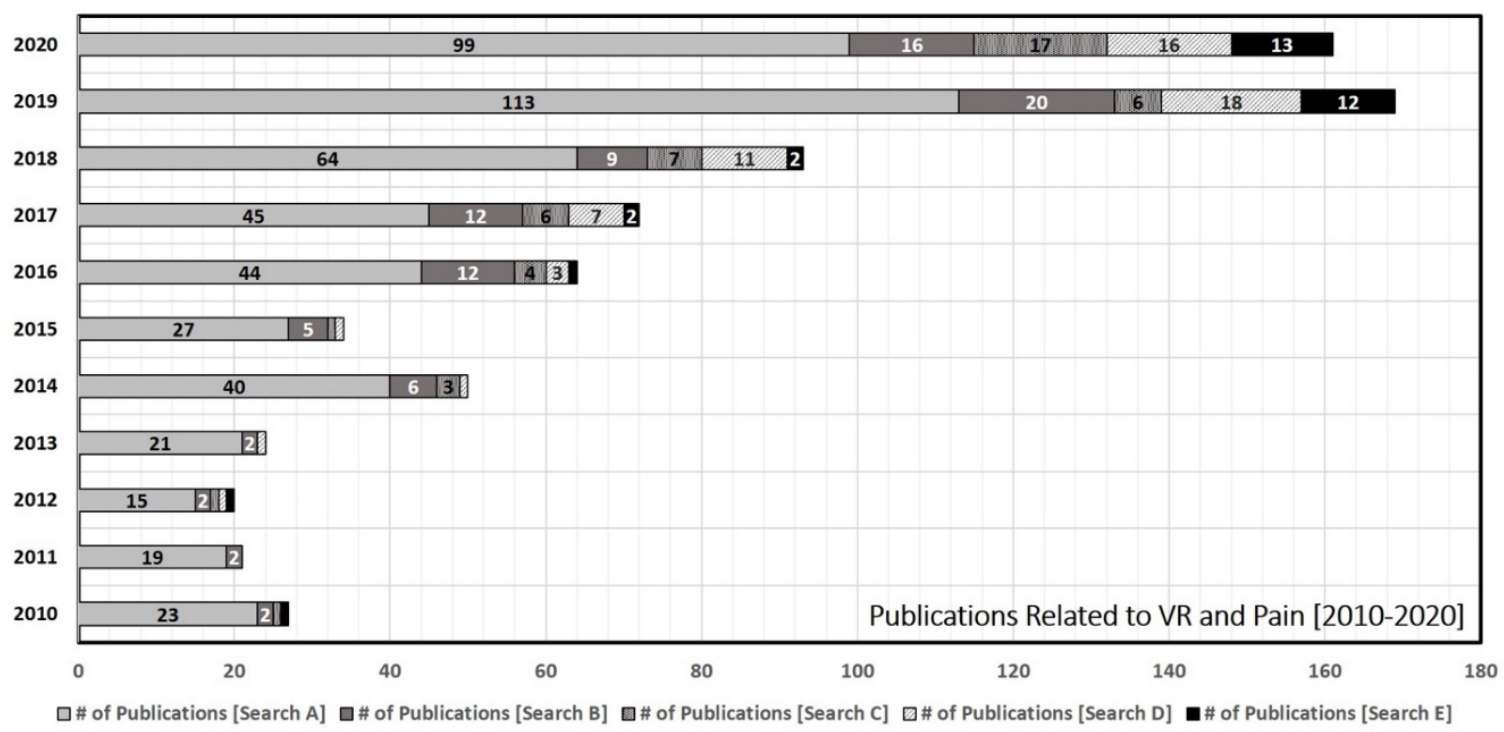

Figure 2. Publications Related to VR and Pain (2010-2020) 


\section{Literature Review and Methodology}

In this systematic review, we performed an additional meta-analysis. The meta-analysis style of review, in general, aims to summarize quantitative data from a pre-defined set of studies to make claims about what is known or not known in a given area (Pigott et al, 2020). Such studies synthesize the quantitative results from earlier studies using various statistical methods to improve data quality and reduce risk of bias. The primary objective of our work was to explore the fundamental questions: how effective is VR in pain management and what challenges are prevalent that require further attention? This is to inform appropriate study designs for future studies and interventions.

As part of this work, various meta-analysis or systematic reviews reported between 2018 and July of 2020 were reviewed and analyzed for their key goals, intervention approaches, study designs and conditions, and reported outcomes. Key word searches were done on terms such as "virtual reality" AND "pain" present in title or abstract, which yielded 392 articles published since 2015. For the scope of the current work, focus was given to earlier metaanalysis or systematic review works on chronic and acute pain that were published in peer reviewed journals. Searched databases included Google scholar, PubMed, and PubMed Central. Citations, retracted articles, patents, conference abstracts as well as individual dissertations were excluded. Additionally, to obtain more reliable results, this metaanalysis was restricted to studies that relied on randomized controlled trials (RCTs), which usually have a high-level of evidence. This yielded 12 publications, which met the study criteria and were analyzed as part of this review work. Primary findings of past meta-analysis work in scope for this study are summarized in Table 1. Key databases, scope of their search, primary goals of the study, pain conditions, pain measurement mechanisms, interventions details, and primary findings by the authors were closely reviewed and analyzed.

\section{Discussion}

Analysis of the meta-analysis works listed in Table 1 shows that there are encouraging results as well as concerns that are impediments in the effective use of VR for pain management. The underlying clinical studies included in scope for these listed works were a mix of randomized control (RCT) and non-random or pre-post intervention (quasi-experimental design) trials, which included 8 - 150 patients, in age groups ranging from 8 to 85 years. Pain conditions range from acute pain as a result of mild injury to chronic pain resulting from serious trauma. Patient reported pain pre- and post-VR exposure sessions, which varied from 5 through 90 minutes, were mainly mostly tracked using the Visual Analog Scale (VAS), Numeric Rating Scale (NRS), and in some cases using the McGill Pain Questionnaire (MPQ). A variety of VR gadgets, which widely differ in their design, performance, and features, were used in these interventions. While some of the studies involved the use of expensive products like ProView family of HMDs, other studies relied on screen time using DVD players. Studies have shown that there is a strong dependency on the type of VR systems used on patient's perceived experience on pain and immersion (Grassini et al., 2020). For example, in a recent study focused on presence and self-efficacy, users indicated a higher sense of spatial presence and immersion while using VR HMD than when using desktop VR (Yu Shu et al., 2019).

Despite the diversity in the study design, such as underlying pain conditions and interventions, some common themes emerge from these meta-analysis studies. While VR qualitatively helps in pain management, there is minimal consensus on its efficacy. Key benefits of VR therapy cited include the following: a) VR therapy reduces acute pain 
condition (Mallari et al., 2019 and Chuan et al., 2020), (b) Its use in perioperative period could effectively relieve postoperative pain (Ding, et al., 2020 and Georgescu et al., 2019), c) VR distraction providing immersive environments wherein patients interact with the virtual scenario appear most effective (Eijlers et al, 2019 and Chuan et al., 2020), and d) VR use is effective for short-term pain relief in both acute and chronic pain (Pourmand et al., 2018 and Luo, 2019). These studies also cited serious limitations, which broadly fall under following themes: 1) Lack of systematic protocols in VR intervention, 2) Significant heterogeneity in study populations, pain conditions, and pain reporting mechanisms used in those underlying studies, 3) Limited number of studies for overcoming biases, and 4) Lack of blinded participant groups and intervention delivery, which are critical for minimizing bias and improving data quality. It is important to note that VR as a technology in intervention studies makes it difficult to blind study participants.

Many of the limitations observed in these studies can be overcome by increasing patient sizes in RCTs, standardization of the intervention protocols, and moving from subjective to objective pain and immersion measurements. For example, studies have shown that biophysical parameter measurements, such as heart rate variability (HRV) and skin conductance using sensor-based pain monitoring technologies, can help measure pain objectively (Naranjo-Hernández et al., 2020). Though research on the immersion process is still in its infancy, the degree of immersion has been found to be a critical factor in improving the target patient engagement (Servotte et al., 2020). The level of immersion can be enhanced by taking a closer look at 5 key VR characteristics, which are presence, interactivity, social interactions, customization, and embodiment illustrated in Figure 3 (Won et al., 2017). "Presence" is the sheer subjective experience of being in an environment as if it were real. The sense of presence can be improved by high fidelity systems, which are a combination of high-end hardware and software applications (Chuan et al, 2020). "Interactivity" is the ability to engage the user with the system in order to enhance user experience. Systems built with skill-building features in applications, characterized by dynamic feedback to the patient as opposed to simple distraction features, will help improve this (Ahmadpour et al., 2020).

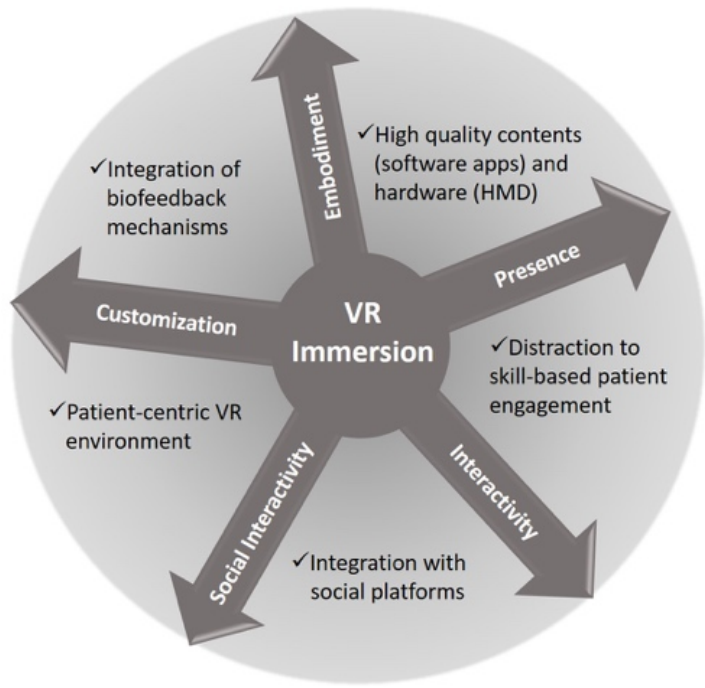

Figure 3. VR Design Considerations for Higher Immersion 
"Social interaction" is the capability that helps a patient interact with their family and friends. A recent pilot study has reported higher tolerance for pain when participants interacted with their loved ones (Hwang et al., 2020). "Customization" is the ability to choose a VR environment based on a patient's conditions and choices. It can be realized by personalizing the VR scenes and ambience based on patient's age group, physical conditions, and ethnic backgrounds (Eijlers et al., 2019). "Embodiment" is defined as the sense of having a body, which can be considered to be both the subject and object of medical science and practice (Marta et al., 2019). The use of body trackers, such as hand trackers, are found to help patients track their real-life movements represented by the movements of their avatars in virtual reality. Specifically, studies have shown that personalized avatars can significantly increase the body ownership and feel of presence and thus the immersion (Waltemate et al, 2018). Recent developments in the field of biomedical engineering, such as the OpenButterfly platform, have already started building dynamically controllable environments to meet various needs identified in this work (Powell et al., 2020).

\section{Conclusion}

Virtual Reality is a powerful, non-pharmacological technique in treating acute pain conditions and limit patients slipping into chronic pain conditions. The strong surge in the number of studies focused on VR intervention for pain management since 2018 is a direct indication of the significant promise this technology holds in treating pain, which in turn is a necessary step in the fight against the opioid crisis. Intervention studies done to-date are mostly vague on efficacy due to the lack of systematic protocols and heterogeneity in study conditions and methodological biases inherent in the observations. Future studies should focus on enhancing the level of immersion by taking a closer look at the design considerations surrounding VR and biofeedback mechanisms highlighted in this work to improve objectivity in pain and immersion measurements.

\section{Study Limitation}

This review relied on previous reviews published on the indicated search topics since 2018 in PubMed, PubMed Central, and Google Scholar and excluded conference proceedings as well as other direct clinical studies. It is important to note that the randomized trial studies provide the highest level of evidence because they contain the least amount of bias while meta-analyses increase bias.

Table 1. Meta-Analysis Summary

\begin{tabular}{|c|c|c|c|c|c|}
\hline Author & $\begin{array}{l}\text { Work Type and } \\
\text { Scope }\end{array}$ & $\begin{array}{l}\text { Primary } \\
\text { Study Goal }\end{array}$ & $\begin{array}{l}\text { Pain Condi- } \\
\text { tions }\end{array}$ & $\begin{array}{l}\text { Intervention De- } \\
\text { tails }\end{array}$ & $\begin{array}{l}\text { Primary Findings / } \\
\text { Outcomes }\end{array}$ \\
\hline $\begin{array}{l}\text { Eijlers } \\
\text { et al. } \\
(2019)\end{array}$ & $\begin{array}{l}\text { Type: Meta-analysis. } \\
\text { DBs: EMBASE, } \\
\text { MEDLINE, } \\
\text { CENTRAL, Pub- } \\
\text { Med, Web of Sci- } \\
\text { ence, and PsycINFO }\end{array}$ & $\begin{array}{l}\text { Determine if } \\
\text { virtual real- } \\
\text { ity }(\mathrm{VR}) \text { is } \\
\text { effective in } \\
\text { reducing } \\
\text { pain and } \\
\text { anxiety in }\end{array}$ & $\begin{array}{l}\text { Pain source: } \\
\text { Burn, onco- } \\
\text { logical care } \\
\text { and venous } \\
\text { access; Pain } \\
\text { and anxiety }\end{array}$ & $\begin{array}{l}\text { Study designs } \\
\text { covered: RCTs } \\
\text { (crossover and par- } \\
\text { allel) } \\
\text { VR Use: I-glasses } \\
\text { 920HR, nVisor } \\
\text { SX, ProView }\end{array}$ & $\begin{array}{l}\text { VR is an effective } \\
\text { tool to diminish pa- } \\
\text { tient-reported pain; } \\
\text { VR interventions for } \\
\text { pain and anxiety } \\
\text { were potentially } \\
\text { more efficacious for }\end{array}$ \\
\hline
\end{tabular}




\begin{tabular}{|c|c|c|c|c|c|}
\hline & $\begin{array}{l}\text { Search Term: VR+ } \\
\text { Children+ adoles- } \\
\text { cents } \\
\text { Study Size: } 17 \\
\text { Patient Size: } 8 \text { to } \\
143 \\
\text { Patient Age: } 4 \text { to } 19 \\
\text { Study Quality As- } \\
\text { sessment: Delphi } \\
\text { List for RCT }\end{array}$ & $\begin{array}{l}\text { pediatric pa- } \\
\text { tients under- } \\
\text { going medi- } \\
\text { cal proce- } \\
\text { dures. }\end{array}$ & $\begin{array}{l}\text { Pain scale: } \\
\text { VAS }\end{array}$ & $\begin{array}{l}\text { XL50, eMagin } \\
\text { z800, intervention } \\
\text { during- restorative } \\
\text { treatment, chemo- } \\
\text { therapy, lumber } \\
\text { puncture, MRI, } \\
\text { and post burn } \\
\text { physiotherapy }\end{array}$ & $\begin{array}{l}\text { younger than for } \\
\text { older children; VR } \\
\text { distraction is possi- } \\
\text { bly more effective } \\
\text { than other distraction } \\
\text { interventions during } \\
\text { medical procedure; } \\
\text { There was a differ- } \\
\text { ence in effect of VR } \\
\text { for different medical } \\
\text { procedures }\end{array}$ \\
\hline $\begin{array}{l}\text { Mallari } \\
\text { et al. } \\
\text { (2019) }\end{array}$ & $\begin{array}{l}\text { Type: Meta-analysis. } \\
\text { DBs: PubMed, } \\
\text { CINAHL, Trip Data- } \\
\text { base searches done: } \\
2007-2018 \\
\text { Search Term: "Vir- } \\
\text { tual reality AND dis- } \\
\text { traction", "Virtual re- } \\
\text { ality AND pain", and } \\
\text { "Virtual reality AND } \\
\text { analgesia } \\
\text { Study Size: } 20 \\
\text { Patient Size: } 6 \text { to } 98 \\
\text { Patient Age: } 18-70 \\
\text { Study Quality As- } \\
\text { sessment: PEDro } \\
\text { tool }\end{array}$ & $\begin{array}{l}\text { To compare } \\
\text { the effec- } \\
\text { tiveness of } \\
\text { VR in reduc- } \\
\text { ing acute } \\
\text { and chronic } \\
\text { pain in } \\
\text { adults com- } \\
\text { pared to } \\
\text { standard } \\
\text { care without } \\
\text { VR }\end{array}$ & $\begin{array}{l}\text { Pain source: } \\
\text { (Acute) Pain } \\
\text { related to } \\
\text { burns and } \\
\text { medical pro- } \\
\text { cedures; mus- } \\
\text { culoskeletal, } \\
\text { neuropathic, } \\
\text { mixed mus- } \\
\text { culoskeletal, } \\
\text { and neuro- } \\
\text { pathic or un- } \\
\text { specified } \\
\text { chronic pain } \\
\text { conditions } \\
\text { Pain scale: } \\
\text { VAS, NRS }\end{array}$ & $\begin{array}{l}\text { Study Design: } \\
\text { RCT Parallel } \\
\text { VR Use: } \\
\text { Oculus Rift (Dk2); } \\
\text { Samsung Galaxy } \\
\text { S5+ Gear, for } 6 \text { - } \\
20 \text { min, during and } \\
\text { after the proce- } \\
\text { dures }\end{array}$ & $\begin{array}{l}\text { VR is an effective } \\
\text { tool in reducing } \\
\text { acute pain both dur- } \\
\text { ing and after a VR } \\
\text { intervention, and that } \\
\text { VR is especially ef- } \\
\text { fective in mitigating } \\
\text { medical procedure } \\
\text { related pain (MPRP) }\end{array}$ \\
\hline $\begin{array}{l}\text { B.Chi et } \\
\text { al., (2019) }\end{array}$ & $\begin{array}{l}\text { Type: Systematic } \\
\text { Review } \\
\text { DB: MEDLINE, } \\
\text { PubMed, CINAHL, } \\
\text { EMBASE, and } \\
\text { PsycINFO. } \\
\text { Search Terms: spi- } \\
\text { nal cord injury, tetra- } \\
\text { plegia, quadriplegia, } \\
\text { or paraplegia with } \\
\text { "virtual reality" } \\
\text { (2007-2018) } \\
\text { Study Size: } 9 \\
\text { Patient Size: } 150 \\
\text { Patient Age: } 20-50 \\
\text { Study Quality As- } \\
\text { sessment: Spinal } \\
\text { Cord Injury Research } \\
\text { Evidence }\end{array}$ & $\begin{array}{l}\text { Systematic } \\
\text { review to in- } \\
\text { vestigate the } \\
\text { effect of VR } \\
\text { therapy on } \\
\text { SCI- } \\
\text { associated } \\
\text { neuropathic } \\
\text { pain }\end{array}$ & $\begin{array}{l}\text { Pain source: } \\
\text { Spinal cord } \\
\text { injury (SCI) } \\
\text { Pain Scale: } \\
\text { NRS, VAS, } \\
\text { McGill pain } \\
\text { questionnaire } \\
\text { (MPQ) }\end{array}$ & $\begin{array}{l}\text { Study Design: } \\
\text { RCT, pre-post } \\
\text { studies } \\
\text { VR Use: Varied } \\
\text { protocols; 10-min } \\
\text { session to } 33 \text { ses- } \\
\text { sions of } 90 \text { min } \\
\text { each over a 6- } \\
\text { month period; VR } \\
\text { therapy methods } \\
\text { such as virtual } \\
\text { walking, VR- } \\
\text { augmented train- } \\
\text { ing, virtual illu- } \\
\text { sion, and VR hyp- } \\
\text { nosis }\end{array}$ & $\begin{array}{l}\text { VR therapy could re- } \\
\text { duce SCI-associated } \\
\text { neuropathic pain; } \\
\text { Clinical trials evalu- } \\
\text { ating VR therapy as } \\
\text { standalone and/or ad- } \\
\text { junct therapy for } \\
\text { neuropathic pain in } \\
\text { SCI patients are war- } \\
\text { ranted }\end{array}$ \\
\hline
\end{tabular}




\begin{tabular}{|c|c|c|c|c|c|}
\hline & $\begin{array}{l}\text { (SCIRE), PEDRo, D } \\
\text { and B scores }\end{array}$ & & & & \\
\hline $\begin{array}{l}\text { Georgescu } \\
\text { et al., } \\
(2020)\end{array}$ & $\begin{array}{l}\text { Type: Meta-analysis } \\
\text { DB: PubMed, } \\
\text { EMBASE, the } \\
\text { Cochrane Library, } \\
\text { and PsycINFO } \\
\text { Search Terms: Vir- } \\
\text { tual reality, game, in- } \\
\text { terface, immersion, } \\
\text { virtual reality expo- } \\
\text { sure therapy, pain, } \\
\text { burn, wound, and in- } \\
\text { juries } \\
\text { Study Size: } 27 \\
\text { Patient Size: } 8-70 \\
\text { Patient Age: Chil- } \\
\text { dren, Adults } \\
\text { Study Quality As- } \\
\text { sessment: Risk of } \\
\text { Bias (RoB) }\end{array}$ & $\begin{array}{l}\text { To assess } \\
\text { the efficacy } \\
\text { and safety of } \\
\text { VR-based } \\
\text { psychologi- } \\
\text { cal interven- } \\
\text { tions for } \\
\text { pain associ- } \\
\text { ated to med- } \\
\text { ical } \\
\text { procedures }\end{array}$ & $\begin{array}{l}\text { Pain source: } \\
\text { Dental, burn, } \\
\text { wound proce- } \\
\text { dures } \\
\text { Pain Scale: } \\
\text { VAS, GRS }\end{array}$ & $\begin{array}{l}\text { Study Design: } \\
\text { RCTs (crossover } \\
\text { and parallel) } \\
\text { VR Use: VR + } \\
\text { pharmacological } \\
\text { treatments }\end{array}$ & $\begin{array}{l}\text { VR-based interven- } \\
\text { tions reduced pain } \\
\text { for patients undergo- } \\
\text { ing medical Proce- } \\
\text { dures; Adjunct VR } \\
\text { therapy for pain } \\
\text { management in hos- } \\
\text { pitalized patients } \\
\text { could reduce costs. }\end{array}$ \\
\hline $\begin{array}{l}\text { Chuan et } \\
\text { al., (2020) }\end{array}$ & $\begin{array}{l}\text { Type: Narrative Re- } \\
\text { view } \\
\text { DB: Medline; Pub- } \\
\text { Med and PsychINFO } \\
\text { Search Term: virtual } \\
\text { reality AND (analge- } \\
\text { sia OR pain) } \\
\text { Study Size: } 18 \\
\text { Patient Size: } 20-98 \\
\text { Patient Age: } 18-75 \\
\text { Study Quality As- } \\
\text { sessment: Cochrane } \\
\text { risk of bias assess- } \\
\text { ment tool }\end{array}$ & $\begin{array}{l}\text { To evaluate } \\
\text { clinical stud- } \\
\text { ies that used } \\
\text { virtual real- } \\
\text { ity in adult } \\
\text { patients for } \\
\text { management } \\
\text { of acute and } \\
\text { chronic pain }\end{array}$ & $\begin{array}{l}\text { Pain Source: } \\
\text { Acute and } \\
\text { Chronic pain } \\
\text { conditions } \\
\text { such as- hand } \\
\text { trauma sur- } \\
\text { gery, } \\
\text { postoperative } \\
\text { wound } \\
\text { dressing } \\
\text { changes, First } \\
\text { stage labor, } \\
\text { Stage 1-4 } \\
\text { breast cancer } \\
\text { patients. } \\
\text { Post-surgical } \\
\text { chronic pain, } \\
\text { Cervical lum- } \\
\text { bar spine pain } \\
\text { Pain Scale: } \\
\text { VAS, NRS }\end{array}$ & $\begin{array}{l}\text { Study Design: } \\
\text { RCT (unblinded), } \\
\text { Crossover RCT, } \\
\text { Observational } \\
\text { VR Use: GearVR, } \\
\text { Samsung, Oculus } \\
\text { Rift; } 30 \text { min of a } \\
\text { single instance of } \\
\text { virtual reality ex- } \\
\text { posure, for } 3 \\
\text { weeks }\end{array}$ & $\begin{array}{l}\text { Higher fidelity soft- } \\
\text { ware provided more } \\
\text { analgesia than lower } \\
\text { fidelity and better } \\
\text { than non-virtual real- } \\
\text { ity controls; Degree } \\
\text { of virtual reality im- } \\
\text { mersion is more ef- } \\
\text { fective than the same } \\
\text { content delivered by } \\
\text { traditional two- di- } \\
\text { mensional television } \\
\text { screens }\end{array}$ \\
\hline $\begin{array}{l}\text { Ahmad et } \\
\text { al., (2020) }\end{array}$ & $\begin{array}{l}\text { Type: Meta-Analysis } \\
\text { DB: EBSCO, Sci- } \\
\text { ence Direct, } \\
\text { MEDLINE, } \\
\text { EMBASE, PubMed, }\end{array}$ & $\begin{array}{l}\text { To summa- } \\
\text { rize and } \\
\text { evaluate the } \\
\text { methodolog- } \\
\text { ical quality }\end{array}$ & $\begin{array}{l}\text { Pain Source: } \\
\text { Chemother- } \\
\text { apy, port ac- } \\
\text { cess/veni- } \\
\text { puncture }\end{array}$ & $\begin{array}{l}\text { Study Design: } \\
\text { RCT and quasi-ex- } \\
\text { perimental design } \\
\text { (8 studies) }\end{array}$ & $\begin{array}{l}\text { VR intervention may } \\
\text { be beneficial for the } \\
\text { management of pain } \\
\text { and anxiety in pa- } \\
\text { tients }\end{array}$ \\
\hline
\end{tabular}




\begin{tabular}{|c|c|c|c|c|c|}
\hline & $\begin{array}{l}\text { Scopus, and CI- } \\
\text { NAHL's DB from } \\
1999 \text { - } 2018 \\
\text { Search Term: virtual } \\
\text { reality, environment, } \\
\text { pain, anxiety, cancer- } \\
\text { related pain, cancer- } \\
\text { anxiety, patients with } \\
\text { cancer, malignancy, } \\
\text { carcinoma, and tu- } \\
\text { mor } \\
\text { Study Size: } 13 \\
\text { Patient Size: } 11-132 \\
\text { Patient Age: } 5-85 \\
\text { Study Quality As- } \\
\text { sessment: Downs } \\
\text { and Black quality } \\
\text { checklist }\end{array}$ & $\begin{array}{l}\text { of primary } \\
\text { studies on } \\
\text { the virtual } \\
\text { reality (VR) } \\
\text { technology } \\
\text { for the man- } \\
\text { agement of } \\
\text { pain and } \\
\text { anxiety } \\
\text { among pa- } \\
\text { tients with } \\
\text { cancer, and } \\
\text { to analyze } \\
\text { the } \\
\text { effectiveness } \\
\text { of VR in the } \\
\text { reviewed } \\
\text { studies }\end{array}$ & $\begin{array}{l}\text { Procedure } \\
\text { Pain Scale: } \\
\text { VAS, NRS }\end{array}$ & $\begin{array}{l}\text { VR Use: } 3-5 \\
\text { minutes during } \\
\text { painful procedures, } \\
\text { from } 45-90 \\
\text { minutes during } \\
\text { chemotherapy in- } \\
\text { fusions, and for } \\
\text { around } 30 \text { minutes } \\
\text { during hospitaliza- } \\
\text { tion and the fol- } \\
\text { low-up from 0-48 } \\
\text { hours after the end } \\
\text { of the VR interven- } \\
\text { tion }\end{array}$ & $\begin{array}{l}\text { with cancer; Com- } \\
\text { pared with standard } \\
\text { care, VR plus stand- } \\
\text { ard care was more } \\
\text { effective in reducing } \\
\text { pain and anxiety in } \\
\text { patients with cancer. }\end{array}$ \\
\hline $\begin{array}{l}\text { Chan et } \\
\text { al., (2018) }\end{array}$ & $\begin{array}{l}\text { Type: Meta-Analysis } \\
\text { DB: MEDLINE, } \\
\text { Embase, CINAHL, } \\
\text { ERIC, NIHR } \\
\text { Search Term: virtual } \\
\text { reality, simulation, } \\
\text { and pain } \\
\text { Study Size: } 20 \\
\text { Patient Size: } 11-132 \\
\text { Patient Age: } 5-80 \\
\text { Study Quality As- } \\
\text { sessment: Manual }\end{array}$ & $\begin{array}{l}\text { A systematic } \\
\text { review and } \\
\text { meta-analy- } \\
\text { sis to ap- } \\
\text { praise the } \\
\text { quality of } \\
\text { published } \\
\text { literature } \\
\text { and to syn- } \\
\text { thesize data } \\
\text { for acute } \\
\text { pain scores }\end{array}$ & $\begin{array}{l}\text { Pain Source: } \\
\text { Peripheral in- } \\
\text { travenous } \\
\text { cannula, port } \\
\text { access, injury } \\
\text { from burn } \\
\text { wounds, epi- } \\
\text { siotomy, and } \\
\text { repair } \\
\text { Pain Scale: } \\
\text { VAS, NPRS, } \\
\text { GRS, VNS, } \\
\text { VAT }\end{array}$ & $\begin{array}{l}\text { Study Design: } \\
\text { RCT and Crosso- } \\
\text { ver } \\
\text { VR Use: Interac- } \\
\text { tive } \\
\text { games, HMD via } \\
\text { laptop, blue-ray } \\
\text { and DVD players }\end{array}$ & $\begin{array}{l}\text { VR is effective for } \\
\text { burns physical ther- } \\
\text { apy } \\
\text { and needles }\end{array}$ \\
\hline $\begin{array}{l}\text { Pourmand } \\
\text { et al., } \\
(2018)\end{array}$ & $\begin{array}{l}\text { Type: Review } \\
\text { DB: PubMed } \\
\text { Search term: virtual } \\
\text { reality pain, 5-year } \\
\text { span } \\
\text { Study Size: } 28 \\
\text { Patient Size: } 25-74 \\
\text { Patient Age: N/A } \\
\text { Study Quality As- } \\
\text { sessment: NR }\end{array}$ & $\begin{array}{l}\text { To evaluate } \\
\text { the use of } \\
\text { virtual real- } \\
\text { ity (VR) } \\
\text { therapies as } \\
\text { a clinical } \\
\text { tool for the } \\
\text { management } \\
\text { of acute and } \\
\text { chronic } \\
\text { pain }\end{array}$ & $\begin{array}{l}\text { Pain Source: } \\
\text { Acute and } \\
\text { chronic pains } \\
\text { from fibrom- } \\
\text { yalgia, phan- } \\
\text { tom limb } \\
\text { pain, and re- } \\
\text { gional spe- } \\
\text { cific pain } \\
\text { from past in- } \\
\text { juries } \\
\text { and illnesses }\end{array}$ & $\begin{array}{l}\text { Study Design: } \\
\text { Randomized con- } \\
\text { trolled trial (RCT) } \\
\text { and Crossover } \\
\text { VR Use: HMDs } \\
\text { (Oculus Rift Dk2), } \\
\text { videos }\end{array}$ & $\begin{array}{l}\text { Study demonstrates } \\
\text { the } \\
\text { potential for VR dis- } \\
\text { traction therapy to } \\
\text { provide effective an- } \\
\text { algesia for patients } \\
\text { experiencing varied } \\
\text { pain across many } \\
\text { settings }\end{array}$ \\
\hline
\end{tabular}




\begin{tabular}{|c|c|c|c|c|c|}
\hline & & & $\begin{array}{l}\text { Pain Scale: } \\
\text { VAS, self-re- } \\
\text { port } \\
\text { question- } \\
\text { naires }\end{array}$ & & \\
\hline $\begin{array}{l}\text { Ding et } \\
\text { al., (2020) }\end{array}$ & $\begin{array}{l}\text { Type: Meta-Analysis } \\
\text { DB: PubMed (Med- } \\
\text { line), Embase, } \\
\text { Web of Science, } \\
\text { Cochrane Controlled } \\
\text { Register of Trials } \\
\text { (CENTRAL), } \\
\text { Proquest, Scopus, } \\
\text { CNKI, WanFang, } \\
\text { and Sinomed [2013- } \\
\text { 2019] } \\
\text { Search Terms: vir- } \\
\text { tual reality, VR, im- } \\
\text { mersi*, distract*, } \\
\text { postoperative } \\
\text { period, after surgery, } \\
\text { follow* surgery, fol- } \\
\text { low* operati*, pain } \\
\text { and analgesi* } \\
\text { Study Size: } 8 \\
\text { Patient Size: } 30-182 \\
\text { Patient Age: } 20-78 \\
\text { Study Quality As- } \\
\text { sessment: Cochrane } \\
\text { risk of bias tool }\end{array}$ & $\begin{array}{l}\text { To explore } \\
\text { the effects of } \\
\text { VR on re- } \\
\text { lieving post- } \\
\text { operative } \\
\text { pain }\end{array}$ & $\begin{array}{l}\text { Knee, dental, } \\
\text { spine surgery } \\
\text { Pain Scales: } \\
\text { VAS, NRS }\end{array}$ & $\begin{array}{l}\text { Study Design: } \\
\text { RCTs } \\
\text { VR Use: before, } \\
\text { after and during } \\
\text { surgery for 5-60 } \\
\text { min duration }\end{array}$ & $\begin{array}{l}\text { VR intervention dur- } \\
\text { ing perioperative pe- } \\
\text { riod could effectively } \\
\text { relieve postoperative } \\
\text { pain }\end{array}$ \\
\hline $\begin{array}{l}\text { Wittkopf } \\
\text { et al., } \\
\text { (2019) }\end{array}$ & $\begin{array}{l}\text { Type: Systematic } \\
\text { Review } \\
\text { DB: Medline (Ovid), } \\
\text { PsychInfo, CINAHL, } \\
\text { Cochrane library and } \\
\text { Web of Science } \\
\text { Search Terms: NR } \\
\text { Study Size: } 13 \\
\text { Patient Size: 9-90 } \\
\text { Patient Age: } 18-65 \\
\text { Study Quality As- } \\
\text { sessment: The } \\
\text { Cochrane Risk of } \\
\text { Bias and National } \\
\text { Heart, Lung, and } \\
\text { Blood Institute tools }\end{array}$ & $\begin{array}{l}\text { To evaluate } \\
\text { the effect of } \\
\text { immersive } \\
\text { and non-im- } \\
\text { mersive in- } \\
\text { teractive vir- } \\
\text { tual reality } \\
\text { on pain } \\
\text { perception } \\
\text { in patients } \\
\text { with a clini- } \\
\text { cal pain con- } \\
\text { dition }\end{array}$ & $\begin{array}{l}\text { Pain Source: } \\
\text { Chronic neck, } \\
\text { low-back } \\
\text { pain, Anky- } \\
\text { losing, Spon- } \\
\text { dylitis, breast } \\
\text { cancer, post- } \\
\text { spinal cord } \\
\text { injury } \\
\text { Pain Scale: } \\
\text { VAS, NRS, } \\
\text { McGill Pain } \\
\text { Questionnaire }\end{array}$ & $\begin{array}{l}\text { Study Design: } \\
\text { RCTs, pre-test } \\
\text { post-test without } \\
\text { control groups. } \\
\text { VR Use: Xbox } \\
360 \\
\text { Kinect - games, } \\
\text { Wii games }\end{array}$ & $\begin{array}{l}\text { There is not enough } \\
\text { evidence to judge the } \\
\text { effectiveness of the } \\
\text { use of virtual reality } \\
\text { for the management } \\
\text { of pain }\end{array}$ \\
\hline
\end{tabular}




\begin{tabular}{|c|c|c|c|c|c|}
\hline $\begin{array}{l}\text { De Araújo } \\
\text { et al., } \\
(2019)\end{array}$ & $\begin{array}{l}\text { Type: Systematic } \\
\text { Review } \\
\text { DB: PubMed, BVS, } \\
\text { Web of Science, } \\
\text { Cochrane } \\
\text { Central, and Scielo } \\
\text { databases (Jan, } 1980 \\
\text { to May 1, 2019) } \\
\text { Search Terms: vir- } \\
\text { tual reality OR vir- } \\
\text { tual reality immer- } \\
\text { sion therapy OR vir- } \\
\text { tual reality therapy } \\
\text { OR reality therapy } \\
\text { OR game(s)AND } \\
\text { spinal cord in- } \\
\text { jury(ies) OR } \\
\text { spinal cord trauma } \\
\text { OR paraplegia OR } \\
\text { tetraplegia. } \\
\text { Study Size: } 25 \\
\text { Patient Size: 6-45 } \\
\text { Patient Age: } 18-65 \\
\text { Study Quality As- } \\
\text { sessment: PEDro } \\
\text { scale }\end{array}$ & $\begin{array}{l}\text { To investi- } \\
\text { gate the pos- } \\
\text { sible bene- } \\
\text { fits and effi- } \\
\text { cacy of VR- } \\
\text { based reha- } \\
\text { bilitation in } \\
\text { individuals } \\
\text { with Spinal } \\
\text { Cord Injury } \\
\text { (SCI) }\end{array}$ & $\begin{array}{l}\text { Pain Source: } \\
\text { Spinal Cord } \\
\text { Injury (SCI) } \\
\text { Pain Scale: } \\
\text { VAS }\end{array}$ & $\begin{array}{l}\text { Study Design: } \\
\text { RCT, non-random- } \\
\text { ized, } \\
\text { Non-blinded, } \\
\text { cross-sectional } \\
\text { VR Use: VR driv- } \\
\text { ing simulator, } \\
\text { CyberGlove + 3D, } \\
\text { Nintendo Wii, } \\
\text { iPad2, Mobile pro- } \\
\text { totype } \\
\text { of the YouKicker } \\
\text { system for } 1 \text { - } 60 \\
\text { minute sessions }\end{array}$ & $\begin{array}{l}\text { Overall, the studies } \\
\text { reported a beneficial } \\
\text { effect of VR therapy } \\
\text { alone or VR associ- } \\
\text { ated with conven- } \\
\text { tional rehabilitation; } \\
\text { Initial evidence of } \\
\text { VR to improve mo- } \\
\text { tor function, motor } \\
\text { skills, balance, and } \\
\text { aerobic function and } \\
\text { to reduce the pain } \\
\text { level was observed }\end{array}$ \\
\hline $\begin{array}{l}\text { Luo et al., } \\
\text { (2019) }\end{array}$ & $\begin{array}{l}\text { Type: } \\
\text { DB: PubMed, } \\
\text { EMBASE, and the } \\
\text { Cochrane Central } \\
\text { Register of Con- } \\
\text { trolled Trials (till } \\
\text { Feb, 2018) } \\
\text { Search Terms: Vir- } \\
\text { tual Reality, Pain } \\
\text { Management, Virtual } \\
\text { Reality Exposure } \\
\text { Therapy, Burn, } \\
\text { wound care, Physical } \\
\text { Therapy Modalities } \\
\text { Study Size: 13 } \\
\text { Patient Size: 8-88 } \\
\text { Patient Age: 5-65 } \\
\text { Study Quality As- } \\
\text { sessment: The } \\
\text { Cochrane Risk of } \\
\text { Bias }\end{array}$ & $\begin{array}{l}\text { Study to ver- } \\
\text { ify the pain- } \\
\text { reducing ef- } \\
\text { ficacy of vir- } \\
\text { tual reality } \\
\text { among burn } \\
\text { patients un- } \\
\text { dergoing } \\
\text { dressing } \\
\text { change or } \\
\text { physical } \\
\text { therapy }\end{array}$ & $\begin{array}{l}\text { Pain Source: } \\
\text { Burns } \\
\text { Pain Scale: } \\
\text { NR }\end{array}$ & $\begin{array}{l}\text { Study Design: } \\
\text { RCT } \\
\text { VR Use: Snow- } \\
\text { World with Spider- } \\
\text { World, with HMD } \\
\text { during dressing } \\
\text { change }\end{array}$ & $\begin{array}{l}\text { The application of } \\
\text { VR coupled with an- } \\
\text { algesics is safe and } \\
\text { effective in reducing } \\
\text { all four components } \\
\text { of pain during burn } \\
\text { patients' dressing } \\
\text { change and physical } \\
\text { therapy sessions }\end{array}$ \\
\hline
\end{tabular}




\section{Acknowledgments}

I would like to thank Dr. Ajay Yekkirala for helping me with this project.

\section{References}

Ahmad, M., Mohammad E. B., and Anshasi H. A. (2020). Virtual Reality Technology for Pain and Anxiety Management among Patients with Cancer: A Systematic Review. Pain Management Nursing, (Article In press). https://doi.org/10.1016/j.pmn.2020.04.002

Ahmadpour, N., Keep, M., Janssen, A., Rouf, A. S., and Marthick, M. (2020). Design Strategies for Virtual Reality Interventions for Managing Pain and Anxiety in Children and Adolescents: Scoping Review. JMIR serious games, 8(1), e14565. https://doi.org/10.2196/14565

Ahn, E. and Kang, H. (2018). Introduction to systematic review and meta-analysis. Korean journal of anesthesiology, 71(2), 103-112. https://doi.org/10.4097/kjae.2018.71.2.103

B. Chi, B. Chau, E.Yeo, and P.Ta (2019). Virtual reality for spinal cord injury-associated neuropathic pain: Systematic review. Annals of Physical and Rehabilitation Medicine, 62 (1), 49-57. https://doi.org/10.1016/j.rehab.2018.09.006

Centers for Disease Control and Prevention (2020, March). Understanding the Epidemic., Retrieved from https://www.cdc.gov/drugoverdose/epidemic/index.html

Chan, E., Foster, S., Sambell, R., and Leong, P. (2018). Clinical efficacy of virtual reality for acute procedural pain management: A systematic review and meta-analysis. PloS one, 13(7), e0200987.

https://doi.org/10.1371/journal.pone.0200987

Chuan, A., Zhou, J. J., Hou, R. M., Stevens, C. J., and Bogdanovych, A. (2020). Virtual reality for acute and chronic pain management in adult patients: a narrative review. Anaesthesia, 10.1111/anae.15202. Advance online publication. https://doi.org/10.1111/anae.15202

Cornick, J.E. and Blascovich, J. (2014), Are Virtual Environments the New Frontier in Obesity Management? Social and Personality Psychology Compass, 8: 650-658. https://doi.org/10.1111/spc3.12141

Cuomo, A., Bimonte, S., Forte, C. A., Botti, G., and Cascella, M. (2019). Multimodal approaches and tailored therapies for pain management: the trolley analgesic model. Journal of pain research, 12, 711-714.

https://doi.org/10.2147/JPR.S178910

De Araújo, A., Neiva, J., Monteiro, C., and Magalhães, F. H. (2019). Efficacy of Virtual Reality Rehabilitation after Spinal Cord Injury: A Systematic Review. BioMed research international, 2019, 7106951. https://doi.org/10.1155/2019/7106951 
Delshad, S. D., Almario, C. V., Fuller, G., Luong, D., and Spiegel, B. (2018). Economic analysis of implementing virtual reality therapy for pain among hospitalized patients. NPJ digital medicine, 1, 41 . https://doi.org/10.1038/s41746-018-0026-4

Ding, L., Hua, H., Zhu, H., Zhu, S., Lu, J., Zhao K., and Xu Q. (2020). Effects of virtual reality on relieving postoperative pain in surgical patients: A systematic review and meta-analysis. International Journal of Surgery, 82, 87-94 https://doi.org/10.1016/j.ijsu.2020.08.033

Eijlers, R., Utens, E., Staals, L. M., de Nijs, P., Berghmans, J. M., Wijnen, R., Hillegers, M., Dierckx, B., and Legerstee, J. S. (2019). Systematic Review and Meta-analysis of Virtual Reality in Pediatrics: Effects on Pain and Anxiety. Anesthesia and analgesia, 129(5), 1344-1353. https://doi.org/10.1213/ANE.0000000000004165

Georgescu, R., Fodor, L. A., Dobrean, A., and Cristea, I. A. (2020). Psychological interventions using virtual reality for pain associated with medical procedures: a systematic review and meta-analysis. Psychological medicine, 50(11), 1795-1807. https://doi.org/10.1017/S0033291719001855

Glare, P., Aubrey, K. R., and Myles, P. S. (2019). Transition from acute to chronic pain after surgery. Lancet (London, England), 393(10180), 1537-1546. https://doi.org/10.1016/S0140-6736(19)30352-6

Grassini, S. and Laumann, K. (2020). Are Modern Head-Mounted Displays Sexist? A Systematic Review on Gender Differences in HMD-Mediated Virtual Reality. Frontiers in psychology, 11, 1604.

https://doi.org/10.3389/fpsyg.2020.01604

Hwang, A., Sun, Y., Tamir N., and Won A. S. (2020). Pain Experience in Social VR: The Competing Effect on Objective Pain Tolerance and Subjective Pain Perception. 2020 IEEE Conference on Virtual Reality and 3D User Interfaces Abstracts and Workshops (VRW), Retrieved from: https://conferences.computer.org/vrtvcg/2020/pdfs/VRW2020-4a2sylMzvhjhioY0A33wsS/653200a579/653200a579.pdf

Jacques E. (2020), 10 Common Types of Pain Scales, Verywellhealth.com, Retrieved from: https://www.verywellhealth.com/pain-scales-assessment-tools-4020329

Johnson, M. I. (2019). The Landscape of Chronic Pain: Broader Perspectives. Medicina, 55(5), 182. MDPI AG. http://dx.doi.org/10.3390/medicina55050182

Leeuw, M., Goossens, M. E., Linton, S. J., Crombez, G., Boersma, K., and Vlaeyen, J. W. (2007). The fearavoidance model of musculoskeletal pain: current state of scientific evidence. Journal of behavioral medicine, 30(1), 77-94. https://doi.org/10.1007/s10865-006-9085-0

Li, A., Montaño, Z., Chen, V. J., and Gold, J. I. (2011). Virtual reality and pain management: current trends and future directions. Pain management, 1(2), 147-157. https://doi.org/10.2217/pmt.10.15

Luo, H., Cao, C., Zhong, J., Chen, J., and Cen, Y. (2019). Adjunctive virtual reality for procedural pain management of burn patients during dressing change or physical therapy: A systematic review and meta-analysis of randomized controlled trials. Wound repair and regeneration: official publication of the Wound Healing Society [and] the European Tissue Repair Society, 27(1), 90-101. https://doi.org/10.1111/wrr.1

Makin S. (2019). The emerging world of digital therapeutics. Nature 573, S106-S109. doi: 10.1038/d41586019-02873-1. Retrieved from https:/www.nature.com/articles/d41586-019-02873-1 
Mallari, B., Spaeth, E. K., Goh, H., and Boyd, B. S. (2019). Virtual reality as an analgesic for acute and chronic pain in adults: a systematic review and meta-analysis. Journal of pain research, 12, 2053-2085. https://doi.org/10.2147/JPR.S200498

Marta, M.G., Tony, D., Sara, B., Giorgio, S., Maria V. S., and Cristina, T. (2019). Immersive Virtual Reality and Virtual Embodiment for Pain Relief, Frontiers in Human Neuroscience, 13, 279. Retrieved from https:/www.frontiersin.org/articles/10.3389/fnhum.2019.00279/full

Naranjo-Hernández, D., Reina-Tosina, J., and Roa, L. M. (2020). Sensor Technologies to Manage the Physiological Traits of Chronic Pain: A Review. Sensors (Basel, Switzerland), 20(2), 365. https://doi.org/10.3390/s20020365

Pain Management Centers of New England (2020), "Pharmacologic Pain Management”, Retrieved from https://www.paincentersofnewengland.com/pharmacologic-pain-management.html

Pigott T.D., and Polanin, J.R. (2020), Methodological Guidance Paper: High-Quality Meta-Analysis in a Systematic Review. The Review of Educational Research (RER), vol. 90 Issue 1, 24-46. https://doi.org/10.3102/0034654319877153

Pourmand, A., Davis, S., Marchak, A., Whiteside, T., and Sikka, N. (2018). Virtual Reality as a Clinical Tool for Pain Management. Current pain and headache reports, 22(8), 53. https://doi.org/10.1007/s11916-018-0708-2

Powell, M. O., Elor, A., Teodorescu, M., and Kurniawan, S. (2020), OpenButterfly: Multimodal Rehabilitation Analysis of Immersive Virtual Reality for Physical Therapy. American Journal of Sports Science and Medicine, 8(1), 23-35. DOI: 10.12691/ajssm-8-1-5, Retrieved from http://pubs.sciepub.com/ajssm/8/1/5/index.html

Schuckit, M. A. (2016). Treatment of Opioid-Use Disorders. N Engl. J Med, 375:357-68, DOI:

10.1056/NEJMra1604339 Retrieved from: https://www.nejm.org/doi/pdf/10.1056/NEJMra1604339

Servotte, J.C., Campbell, S.H., Dardenne, N., Pilote, B., Simoneau, I.L., Guillaume, M., Bragard I., and Ghuysen, A. (2020), Virtual Reality Experience: Immersion, Sense of Presence, and Cybersickness. Clinical Simulation and Nursing, 38, 35-43. https://doi.org/10.1016/j.ecns.2019.09.006

U.S. Department of Health and Human Services (2019, May). Pain Management Best Practices Inter-Agency Task Force Report: Updates, Gaps, Inconsistencies, and Recommendations. Retrieved from U. S. Department of Health and Human Services website: https:/www.hhs.gov/ash/advisory-committees/pain/reports/index.html

Ventola C. L. (2019). Virtual Reality in Pharmacy: Opportunities for Clinical, Research, and Educational Applications. P and T: a peer-reviewed journal for formulary management, 44(5), 267-276. Retrieved from https://www.ncbi.nlm.nih.gov/pmc/articles/PMC6487969

Waltemate, T., Gall, D., Roth, D., Botsch, M., and Latoschik, M. E. (2018). The Impact of Avatar Personalization and Immersion on Virtual Body Ownership, Presence, and Emotional Response. IEEE transactions on visualization and computer graphics, 24(4), 1643-1652. https://doi.org/10.1109/TVCG.2018.2794629 
White House Report (2017, Nov). The Underestimated Cost of the Opioid Crisis. Retrieved from https://www.whitehouse.gov/sites/whitehouse.gov/files/images/The\%20Underesti-

mated $\% 20$ Cost $\% 20$ of $\% 20$ the $\% 20$ Opioid $\% 20$ Crisis.pdf

Wittkopf, P. G., Lloyd, D. M., Coe, O., Yacoobali, S., and Billington, J. (2019). The effect of interactive virtual reality on pain perception: a systematic review of clinical studies. Disability and rehabilitation, 1-12. Advance online publication. https://doi.org/10.1080/09638288.2019.1610803

Won, A. S., Bailey, J., Bailenson, J., Tataru, C., Yoon, I. A., and Golianu, B. (2017). Immersive Virtual Reality for Pediatric Pain. Children (Basel, Switzerland), 4(7), 52. https://doi.org/10.3390/children4070052

Yekkirala, A. S., Roberson, D. P., Bean, B. P., and Woolf, C. J. (2017). Breaking barriers to novel analgesic drug development. Nature reviews. Drug discovery, 16(8), 545-564. https://doi.org/10.1038/nrd.2017.87

Yu Shu, V., Yen-Zhang Huang, Shu-Hsuan, C., and Mu-Yen, C. (2019). Do virtual reality head-mounted displays make a difference? A comparison of presence and self-efficacy between head-mounted displays and desktop computer-facilitated virtual environments. Virtual Reality 23, 437-446. https://doi.org/10.1007/s10055-018$\underline{0376-x}$ 
HIGH SCHOOL EDITION 